\title{
A STRATÉGIAI FÖLDRAJZI HELY FOGALMA A TRANSZNACIONÁLIS VÁLLALATOK NEMZET- KÖZI ÜZLETPOLITIKÁJÁBAN
}

(The Concept of Strategic Geographic Place in the International Business Policy of Transnational Companies)

BERNEK ÁGNES

Kulcsszavak:

stratégiai földrajzi hely nemzetközi üzletpolitika lokalizációs döntések feltörekvő piacok üzleti központok "e-business"

Az utóbbi években a stratégiai fóldrajzi hely a globális szinten szervezódỏ transznacionális vállalatok egyik fontos fogalmává vált. E tanulmány kiemelten a stratégiai jelentôségũ nemzetgazdaságokkal és az üzleti központokkal foglalkozik. Ez utóbbi külön figyelmet érdemel, hiszen Budapest 2000-ben Európa harmadik legjobb üzleti központjának minösült. A stratégiai földrajzi hely fogalma a virtuális térben is értelmezhetö, s az „e-business" terén egyre jelentösebbé válik. Az „e-business” jövôjét valószínüleg a virtuális tér lehetöségei és valós tér adottságai közötti kölcsönös összefüggés illetve ellentmondás szabja meg.

\section{Üzleti stratégia - stratégiai földrajzi hely}

„Minden szervezet ủzleti filozófia alapján müködik, azaz van elképzelése arról, hogy mi a feladata, milyen célokat akar elérni, hogyan határozza meg az eredményességét, valamint arról, hogy kikből tevődik össze az ügyfélköre, és ezek az ügyfelek mit értékelnek annyira, hogy fizetni is hajlandók érte. Az üzleti filozófia gyakorlati megvalósítása a stratégia. Ez teszi lehetővé, hogy egy szervezet, a meglehetősen kiszámíthatatlan külsö körülmények ellenére, elérje kitúzött céljait." (Drucker 2001, 53)

Az üzleti stratégia optimális megvalósításához azonban a vállalatnak meg kell találnia a legkedvezóbb földrajzi helyet, illetve helyeket. Vitathatatlan tény, hogy a világgazdaság ún. ,forró pontjain" vagy más szóval stratégiai fóldrajzi helyein való jelenlét az üzleti siker elengedhetetlen feltétele. E stratégiai földrajzi helyek pontosan kirajzolhatóak mind a transznacionális vállalatok irányító-központjainak lokalizációja, mind leányvállalataik térbeli szervezödése alapján. A nemzetközi üzletpolitika lokalizációs dỏntéseinek egyik legfontosabb célja, hogy kiválassza az adott vállalat mủködéséhez legkedvezőbb stratégiai földrajzi helyet.

Megítélésünk szerint a „stratégiai földrajzi hely” fogalma különbözó térségi szinteken értelmezhetö. Nevezetesen a nemzetközi üzletpolitikában egyaránt stratégiai földrajzi helynek nevezhető egy, a világgazdaságban kiemelkedóen fontos nemzetgazdaság, vagy akár e nemzetgazdaság adott városa is. Ennek hátterében áll az a tény, hogy a globális világgazdaságban elötérbe kerïlt a lokalizáció, hiszen a világ 
egészét átfogó nemzetközi termelés csak az adott földrajzi helyek pontos ismerete alapján lehetséges.

Az 1970-es években a világgazdaság fogalmát rendszerint úgy értelmezték, mint az egyes nemzetállamok összességét és a köztük lévő külkereskedelmi kapcsolatokat. A fokozódó nemzetköziesedés alapmutatójának rendszerint azt tekintették, hogy a II. világháború utáni évtizedekben a nemzetközi kereskedelem növekedési rátája meghaladta a nemzetgazdaságok összteljesítményének alakulását. E nemzetgazdaságok szintjén felépuilö világgazdaságnak megfelelöen, a nemzetközi me. nedzsment szakirodalma a "lokális" kifejezés alatt általában a nemzetgazdaságot (országokat), vagy az ún. nagytérségi régiókat (pl. Európa, Kelet-Ázsia vagy ÉszakAmerika) értette (sőt gyakran érti ma is).

A világgazdaság szerkezeti átalakulása az 1980-1982. évi stagnálás után új irányt vett, s egy töke- és technológia-intenzív növekedési szakasz vette kezdetét. A világgazdaság legfontosabb folyamatai már nem kizárólag az egyes nemzetállamok szintjén valósulnak meg, s az egyes államok közötti gazdasági tranzakciók egyre inkább háttérbe szorulnak a globális szintủ gazdasági folyamatokhoz képest. Korunk világgazdaságát a szakértők olyan átmeneti korszaknak tekintik, amelyben az egyes államok közötti politikai-gazdasági kapesolatok összességén alapuló világgazdasági rendszer egy világméretủ piacgazdaság kialakulása felé halad.

De e globális gazdasági folyamatok már nem elsődlegesen a nemzetgazdasági térszinten szervezödnek, sőt a nemzetállamok korábbi domináns politikai-gazdasági szerepe jelentősen átalakult. A világgazdasági globalizáció területi szerveződésének lényegi eleme, hogy a nemzetgazdasági szint feletti - nemzetközi integrációk - és különösen a nemzetgazdasági szint alatti térségi szintek - regionális gazdaság, lokális gazdaság - szerepe egyre fontosabbá válik. Így a nemzetközi üzletpolitikában is a lokalizáció kifejezése jelentősen átalakul. Vagyis a ,stratégiai földrajzi hely” fogalma immár a nagytérségi erőterek és az országok mellett egyre inkább jelentheti a régiókat, a térségeket, a településeket (Bernek 2000; 2001).

Jelen tanulmány kísérlet a stratégiai földrajzi hely fogalmának meghatározására egyrészt a nemzetgazdaságok, másrészt az üzleti központok felöl. A gazdasági tevékenységek növekvő virtualitása azonban a stratégiai földrajzi hely fogalmát is átértékeli, így tanulmányunk az e-business térbeli szerveződésének vizsgálatával zárul.

\section{Stratégiai jelentöségü nemzetgazdaságok a nemzetközi üzletpolitikában}

A nemzetközi szakirodalom a transznacionális társaságok világgazdasági jelentöségének becslésére rendszeresen felhasználja a vezető amerikai üzleti folyóirat, a Fortune, a világ 500 legnagyobb vállalatára, az ún. „Global 500”-ra vonatkozó jelentését. Ugyanis feltételezhetö, hogy a világ 500 legnagyobb cége világszinten szervezi múködését, vagyis megfelel a transznacionális vállalat kriteriumának. 
A stratégiai földrajzi hely fogalma a transznacionális vállalatok nemzetközi üzletpolitikájában. Tér és Társadalom 15. évf. 2001/3-4. 1-9. p.

TÉT XV.évf. 2001 - 3-4

A stratégiai földrajzi hely...

3

A nemzetgazdaságok szintjén felépüilö világgazdaság és a legnagyobb vállalatok által irányított világpiac egymáshoz viszonyított arányait szemlélteti az 1 . és 2. táblázat.

\section{TÁBLÁZAT}

A három vezetó centrumtérség világgazdasági helyzete - 1999

(The World Economic Situation of the Three Leader Core Region - 1999)

\begin{tabular}{lcc} 
& GNP (milliárd USD) & Részesedés a világ GNP-böl (\%) \\
\hline USA & 8351 & 28,5 \\
EU & 8212 & 28,1 \\
Japán & 4079 & 14,0 \\
Többi ország & 8590 & 29,4 \\
\hline Világ összesen & 29232 & 100,0 \\
\hline
\end{tabular}

Forrás: Fortune 2000 (July 31); World Development Indicators 2001.

\section{TÁBLÁZAT}

A legnagyobb vállalatok (Global 500) jövedelem és profit értékei 1999-ben

(Incomes and Profits of the Largest Companies in 1999-Global 500)

\begin{tabular}{lcccc}
\hline \multirow{2}{*}{ A vállalatok székhelye } & \multicolumn{2}{c}{ Jövedelem } & \multicolumn{2}{c}{ Profit } \\
\cline { 2 - 5 } & milliárd USD & $\%$ & milliárd USD & $\%$ \\
\hline USA & 4681 & 36,9 & 308 & 55,6 \\
EU & 3875 & 30,5 & 178 & 32,1 \\
Japán & 2930 & 23,1 & 22 & 4,0 \\
Többi ország & 1210 & 9,5 & 46 & 8,3 \\
\hline Global 500 összesen & 12696 & 100,0 & 554 & 100,0 \\
\hline
\end{tabular}

Forrás: Fortune 2000 (July 31); World Development Indicators 2001.

1999-ben a „Global 500” összes jövedelme 12,7 billió USD-nek felelt meg, s ez több mint 40\%-a a nemzetgazdaságok összesített GNP-jének. Ami a profit nagyságát illeti, látható, hogy ekkor a világ legnagyobb vállalatai átlagosan összes jövedelmük több mint $4 \%$-át könyvelték el nyereségként.

A fenti táblázat a világgazdaság térbeli koncentrációjára is utal. 1999-ben a világ összes GNP-jének 70\%-át állította elő a három centrumtérség. Ugyanakkor a három centrumtérségben bejegyzett vállalatok a „Global 500” összes jövedelmének és profitjának $90 \%$-ával rendelkeztek.

A világgazdasági globalizáció egyben növeli is a különbségeket a fejlett ipari államok között. 1999-ban a világ 500 legnagyobb cége közül 179-nek volt az anyavállalata az USA-ban, s 1995 és 1999 között az itt bejegyzett legnagyobb cégek száma még növekedett is. Az USA vezető globális világpiaci szerepkörét talán még jobban jellemzi a táblázat azon adata, miszerint a világ legnagyobb vállalatai által elkönyvelt összes profit több mint a fele az USA-ba kerül. Japán gazdasági receszsziójára az is utal, hogy 1999-ben a japán vállalatok a „Global 500" összes profitjából csak 4\%-kal részesedtek. Söt 1995-töl 1999-ig fokozatosan csökkent (közel 140-ról 107-re) a japán vállalatok száma a világ legnagyobb cégeinek rangsorában. 
1999-ben az európai transznacionális cégek a legnagyobb vállalatok összes jövedelméből és profitjából közel 1/3-os aránnyal részesedtek.

1999-ben az ENSZ mintegy 63 ezer transznacionális céget tartott nyílván, s e cégeknek közel 690 ezer külföldi leányvállalata volt. Az anyavállalatok és a leányvállalatok földrajzi megoszlása azonban rendkívül egyenlőtlen. A nemzetközi üzletpolitika lokalizációs döntéseinek alapvető tényezöje, hogy a transznacionális vállalatok anyavállalatainak közel $80 \%$-a a fejlett országokban, a külföldi leányvállalatoknak viszont majdnem $90 \%$-a az alacsony és a közepes jövedelmú államokban található. Ez a nemzetközi üzletpolitika telepítési tényezőinél felértékel bizonyos fejlödő országokat, mint stratégiai jelentőségü földrajzi helyeket. Az ún. „emerging markets" vagyis a feltörekvő piacok közé soroljuk Kínát, ahol mintegy 240 ezer leányvállalat található, $s$ ez a világon lévő összes leányvállalatoknak az 1/3-a. A kelet-és délkelet-ázsiai térségben több mint 80 ezer leányvállalat van, s így a nemzetközi menedzsmentben az exportösztönző iparpolitikát folytató országok igen fontosak. Az 1990-es évek végére a transznacionális vállalatok nemzetközi üzletpolitikájában felértékelődött a kőzép- és kelet-európai régió is, ugyanis a világon lévő összes leányvállalatoknak immár több mint 1/3-a itt lokalizálódik (Bernek 2001).

Általános értelemben véve azt mondhatjuk, hogy a transznacionális vállalatok lokalizációs döntései szabják meg alapvetően azt, hogy mely nemzetgazdaságok, térségek, városok lesznek a stratégiai földrajzi helyek. 1999-ben a transznacionális vállalatok nemzetközi befektetési döntéseinek fontossági sorrendje adott térség megválasztásánál a következőképpen alakult (Simai-Gál 2000):

1) A piac bővülése;

2) A piac nagysága;

3) Profitkilátások;

4) Politikai és társadalmi biztonság;

5) Jogi és szabályozási környezet;

6) A munkaerö minősége;

7) Az üzleti infrastruktúra minősége és az üzleti környezet;

8) Az emberi és pénzügyi erőforrásokhoz való hozzájutás;

9) Bérköltségek;

10) $\mathrm{K}+\mathrm{F}$ források és képességek;

11) Az állami kereskedelempolitika jellege;

12) A nyersanyagforrások közelsége és hozzáférhetösége.

Egyértelmú, hogy a fentiekben rangsorolt nemzetközi telepító-tényezök fontossága változhat attól függően, hogy milyen nemzetiségủ az anyavállalat, illetve, hogy az anyavállalat milyen gazdasági ágazatban tevékenykedik. 


\section{Üzleti központok mint a globális világgazdaság stratégiai földrajzi helyei}

\section{A transznacionális vállalatok központjai (,,headquarter”), mint a globális világ irányító központjai}

A transznacionális vállalat ,headquarter”-e, a továbbiakban HQ-ja a vállalatok működésében meghatározó jelentőséggel bír. A stratégiai döntések teljes körét itt hozzák, a hosszú távú vállalati politika minden tényezöjét itt elemzik

A központi $H Q-k$ meghatározó telepítö-tényezöi a következök:

- A legfontosabb telepítö-tényező a stratégiai földrajzi helyzet. Az 1970-es évek világgazdaságán belül ez főként a gazdasági-politikai szempontból meghatározó szereppel bíró országban, térségben vagy akár településen lévő elhelyezkedést, valamint az igen kedvezö közlekedés-földrajzi helyzetet jelentette. A globális világban mindez kiegészül az információs hálózaton belüli elérhetőséggel, vagyis a virtuális térben lévő stratégiai helyzettel.

- Napjainkban egyre meghatározóbb telepítö-tényező az, hogy a központi illetve a regionális $H Q$-nak teret adó település milyen minöségü üzleti központ. Nevezetesen, hogy milyen jellegủek és föként színvonalúak az itt lévö szolgáltatási tevékenységek. Továbbá, hogy rendelkezésre áll-e speciálisan képzett főleg az információs technológiában jártas - munkaerő. Új fogalomként jelent meg az utóbbi időben az ún. glokális munkás kifejezés, amely adott lokális szinten élö, de a globális világpiac igényének megfelelő képzettségi színvonallal rendelkezö munkavállalót jelenti.

- A vállalati és regionális központok területi agglomerálódási folyamatokat eredményeznek. Adott területi agglomeráció megléte, illetve az ezt elősegítö tényezők önmagukban véve is meghatározó telepítési tényezőket jelentenek. Különösen a földrajzi közelség, az ún. „face-to-face” kontaktus az, amely a vállalatok közötti sokrétủ kapcsolatokat segítik elő.

A globális világgazdaság irányító központjai az ún. ,global city”-k, vagyis a globális városok. New York, Tokió és London a globális világ központjai. E három város nemcsak a legnagyobb vállalatok HQ-jait tömöríti, de egyben a világ legnagyobb pénzügyi központjai is (Bernek 2000).

\section{Regionális jelentöségü üzleti központok}

A központi $H Q$ a transznacionális vállalatok többségében a regionális $H Q-k$ rendszerén át irányítja a vállalatot. Bár a vállalati nemzetközi szakirodalom ezt „regionálisnak” nevezi, de e regionális vállalati központok különbözö térségi szintekhez kapcsolódhatnak. Leggyakrabban nagytérségi régióhoz, pl. Európai Unió vagy Kelet-Közép-Európa vagy akár Délkelet-Ázsia. De kiemelkedỏen fontos nemzetgazdasági piacon - pl. Oroszország vagy Kína - országos jelentőséggel bírnak. E regionális HQ-k általában döntéshozó és irányító jogkörrel az adott befogadó térség 
vonatkozásában rendelkeznek. A transznacionális vállalatok és a nemzetközi pénzügyi folyamatok szoros összefonódására utal, hogy a regionális szerepkőrủ vállalati központok és regionális jelentőségü pénzügyi központok is közel megegyeznek egymással.

A legkedvezőbb regionális üzleti központokról készített felmérést a Fortune magazin, az Arthur Andersen által gyüjtött adatokra támaszkodva (Figyelö 2000, 20-26). A világ 85 városáról hallgatták meg több száz vállalatvezető véleményét. A rangsor megállapításakor figyelembe vették az adott város gazdasági környezetét, az üzleti költségeket, a munkaerỏ árát és kvalitását, valamint az élet minőségét, $\mathrm{s}$ mindezeket a jellemzőket megpróbálták számszerüsíteni. A vizsgált négy kontinensen olyan metropoliszok versengtek, mint New York, Sydney, Hongkong vagy London. Igen nagy optimizmusra adhat alapot hazánk gazdasági jövőjét illetỏen az, hogy az üzleti feltételek minősége annyira kedvezö Budapesten, hogy a magyar föváros a 2000. évi listán Európában - Münchent és Stockholmot is megelözve - a harmadik helyen végzett. E felmérés eredményeit foglalja össze a 3. táblázat.

3. TÁBLÁZAT

A világ legjobb ïzleti központjai

(The Best Head Quarters of the World)

\begin{tabular}{ccccc}
\hline Helyezés & Európa & Észak-Amerika & Latin-Amerika & Ázsia és Ausztrália \\
\hline 1. & London & Dallas & Monterrey & Szingapúr \\
2. & Amszterdam & San Jose* & Mexikó City & Sydney \\
3. & Budapest & Austin & Buenos Aires & Melbourne \\
4. & München & New York & Santiago & Hongkong \\
5. & Stockholm & Atlanta & San Jose** & Tajpej \\
\hline
\end{tabular}

* USA, Kalifornia

** Costa Rica

Forrás: Figyelő 2000, 20-26. o.

Az ázsiai kontinens legjobb üzleti központja és egyben a transznacionális vállalatok regionális HQ-jainak vezető városa Szingapúr. A szingapúri kormányzat az ún. "Operatív HQ terv" keretében dolgozta ki azt a gazdaságpolitikai irányvonalat, amelynek eredményeként napjainkra Szingapúr a transznacionális vállalatok délkelet-ázsiai tevékenységének központja. Ha a stratégiai földrajzi hely fogalmát kellene szemléltetnünk, akkor erre Szingapúr lehetne talán a legjobb példa. De milyen tényezők, tendenciák jellemzik e városállamot?

A Maláj-félsziget déli csuicskénél lévő Szingapúri Köztársaság területe mindössze $646 \mathrm{~km}^{2}$. Lakóinak száma közel 3 millió fö. A külföldröl érkezett vendégmunkások aránya igen magas, jelenleg minden ötödik szingapúri munkavállaló nem helyi lakos. Jelenleg Szingapúr a világ leggazdagabb országai közé tartozik (a GNP/fö értéke 1998-ban 30060 USD volt), s az utóbbi évtizedben a gazdasági fejlődés üteme világszinten is kimagasló.

A rendkívül előnnyös földrajzi helyzetnek, a liberális gazdaságpolitikának, az igen korszerủ infrastruktúrának, a kedvező adózási és pénzügyi feltételeknek, valamint a magas szinten képzett munkaerőnek köszönhetően Szingapúr Földünk egyik legje- 
lentősebb müködőtőke-importáló országa. A világ valamennyi fontos transznacionális cégének van képviselete vagy leányvállalata itt. Az 1990-es évek elejétöl a városállam maga is tőkeexportáló országgá vált. A városállam egyben az ázsiai térség pénzforgalmának egyik legfontosabb központja. Több mint 140 kereskedelmi banknak van itt fiókja. Az ún. spekulációs valutaügyletek terén Szingapúr nemzetközi szinten is rekordforgalmat bonyolít le.

Szingapúr jelenlegi gazdasági életének két legfontosabb ágazata a töke- és technológia-igényes feldolgozóipar és a sokrétü, különösen pénzügyi téren kiemelkedő szolgáltatási szektor. Vezető ágazata az elektronika. A kormányzat jelenlegi és jövőbeli célja a csúcstechnológiai iparágak (pl. a robotgyártás és a biotechnológia) fejlesztése.

A szolgáltatási ágazatok közül a pénzügyi és az üzleti szolgáltatások világszinten a legfejlettebbek közé tartoznak. Napjainkra e két szolgáltatási tevékenységből származik Szingapúr összes GDP-jének közel 1/3-a. Mindez összefüggésben áll azzal, hogy a városállam a világ egyik vezetỏ kereskedelmi központja, Rotterdam után a világ második legnagyobb áruforgalmat lebonyolító kikötője. A városállam hatalmas méretủ közvetítỏkereskedelmet bonyolít le, a reexport az összes kivitelből közel 40\%-kal részesedik (Bernek 1998).

\section{A virtuális tér a nemzetközi üzletpolitikában}

Elektronikus üzlet, vagyis az e-business az üzleti tevékenységek vezetékes és vezeték nélküli, internetes technológián alapuló ơsszekapcsolása a vásárlókkal, a beszállítókkal és az üzleti partnerekkel. Három fỏ csoportját különböztetjük meg:

- business-to-business, B2B (vállalatközi),

- business-to-consumer, B2C (vállalat és végfelhasználó közötti),

- consumer-to-consumer, C2C (végfelhasználók közötti).

Az e-business elterjedését igen jól szemlélteti az a tény, hogy az USA-ban már a katalógusok alapján történő vásárlások $40 \%$-át bonyolítják le a világhálón keresztül. Ugyanez az arány a 7 legfejlettebb országban csak 4-5\%.

Milyen térbeli következményei vannak mindennek? A virtuális térben szervezödő üzleti folyamatokban a földrajzi határok ténylegesen megszünnek?

A e-business szervezödésében a kulcsszó a hálózat. A 21. századot immár egyre többen a hálózatok évszázadának tekintik, s minden földrajzi kötöttségtől mentes kommunikációról beszélnek. Hiszen az e-business révén a mindeddig egymástól elkülönüilt lokális hálózatok, illetve adott lokális szinten mủködỏ vállalatok szinte teljes körủ összefonódása válik lehetségessé. Ennek révén adott vállalat müködésének reális céljává válhat a globális terjeszkedés, a globális világpiacon való megfelelés.

Az e-business révén összefonódó vállalati egységeknek, illetve az addig függetlenül tevékenykedő vállalatoknak mind szorosabb tényleges horizontális és vertikális integrációja válik lehetségessé. Ezért is mondhatjuk azt, hogy az e-business elvileg a nemzetközi üzletpolitikában egészen új távlatokat nyit. 
Azonban ahhoz, hogy virtuális úton a teljes üzletmenet megszervezhető legyen több előfeltételnek együttesen kell érvényesülnie. Elöször is kiemelkedően fontos a technológiai háttér. Az üzleti folyamatok teljes körü, egységes rendszerben történő automatizálása szükségessé teszi az általános keret-megoldásokra alapozható hálózati technológiákat, a vállalaton belúli egyedi fejlesztések helyett. Ehhez kapcsolódik az a tény is, hogy a menedzsment tanácsadás egyik legföbb kérdése, hogyan milyen internetes megoldás szolgálja legjobban az üzleti érdekeket. Magyarországon ez már egyre inkább a vállalati stratégia részét alkotja. Az e-business jelentősége marketingszempontból is kiemelkedő, ugyanis az ügyféllel való kapcsolattartás sokkal olcsóbb az interneten, mint a hagyományos ủgyfélszolgálati irodákban.

Az e-business további nagyon fontos előfeltétele a megfelelóen kiépüll bankrendszer, illetve a szintén virtuális úton szervezett pénzügyi szolgáltatások megléte, illetve minösége. Itt különösen a biztonság kérdését kell kiemelnünk, bár ez elsődlegesen technológiai kérdés is.

Egyre fontosabb hazánkban az elektronikus üzletmenetek jogi szabályozása illetve felügyelete. Erre igen szemléletes példát nyújt a távmunka hazai kérdőjeleiről készült felmérés (Figyelö 2000). Bár a hazai cégvezetök pozitívan viszonyulnak a távmunkához, de mégis félnek beindítani az új modellt, hiszen nem tisztázottak még az adatvédelmi, munkajogi kérdések.

Az előbbi tényezőket összefoglalóan úgy is nevezhetjük, hogy mennyire biztonságosak az ïzleti folyamatok. Az üzleti biztonságot azonban a gazdaság, a társadalom és a politikai rendszer egészének biztonsága szabja meg. Vitathatatlan, hogy az ủzleti biztonságot legföképpen a gazdasági fejlettség határozza meg. Alacsony illetve közepes gazdasági fejlettségi szinten az üzleti folyamatok biztonsági szintje megkérdöjelezhető.

Hogyan fogalmazható meg az e-business jövője a globális világ térszervezödésének szempontjából? Az információs technológiai fejlődés elvileg mindenre lehetöséget ad, $s$ így a virtuális térben a vállalati tevékenység elvileg korlátlanul bővíthetỏ. De ez csak elvileg van így. Hiszen a valós tér, az adott földrajzi helyek gazdasági-társadalmi adottságai még erösen határokat szabnak az e-businessnek. Vagyis a virtuális tér lehetőségei és a valós tér adottságai közötti kölcsönös összefüggés illetve ellentmondás az, amely az e-business jövőjét megszabja.

Másfelől a lokalitás, lokalizáció újrafogalmazásának szükségességét a virtuális térben ugrásszerủen fejlődő e-business is felveti. A virtuális térbeli szerveződés ,jelszava" immár a hálózat. Ennek csomópontjai, más szóval stratégiai földrajzi helyei a virtuális tér irányító központjai, s e csomópontokat az információs csatornăk (információs „szupersztrádák”) kötik össze. Többnyire a virtuális tér irányító központjai megegyeznek a valós tér stratégiai helyeivel, például az ún. globális városokkal. Elviekben az tuzleti tevékenységek virtuális térben történő szerveződése korlátlan, vagy más szavakkal mondhatjuk úgy is, hogy ledölnek a ,földrajzi korlátok".

De a „földrajzi korlátok” eltủnése még csak a virtuális térben valósul meg. Sỏt az olyan virtuális térben, ahol erre a magas gazdasági fejlettségü valós tér lehetőséget ad. Mivel a világgazdasági globalizáció az egyes földrajzi helyek közötti differen- 
ciát rendkívüli mértékben növeli, így az alacsony gazdasági fejlettségi szinten álló földrajzi helyek e virtuális üzleti folyamatokból még kimaradnak. A nemzetközi üzletpolitika jövöbeli kérdése lesz többek között az is, hogy a közepes gazdasági fejlettségi szinten álló földrajzi helyek közül melyek lesznek képesek a világgazdasági globalizációs folyamatokba történỏ minél intenzívebb bekapcsolódásra (Bernek 2001).

\section{Irodalom}

Allen, J.- Hamnett, C. (eds.) (1995) A Shrinking World? Global Unevenness and Inequality. Oxford University Press/The Open University, London.

Bernek Á. (1998) Szingapúr. - Probáld F.- Horváth G. (szerk.) Ázsia, Ausztrália és Óceánia fóldrajza. ELTE Eötvös Kiadó, Budapest.

Bernek Á. (1999) A globális világgazdaság térszervezódése. - Nemes Nagy J. (szerk.) Helyek, terek, régiók. ELTE Regionális Földrajzi Tanszék, Budapest.

Bernek Á. (2000) A globális világ ,új gazdaságföldrajza”, - Tér és Társadalom. 4. 87-107. o.

Bernek Á. (2001) Régiók, térségek a globális világban. - Poór J.-Farkas F. (szerk.) Nemzetközi menedzsment. KJK-Kerszöv Jogi és ìzleti kiadó, Budapest.

Dicken, P. (1992) Global Shift. The Internationalization of Economic Activity. Paul Chapman Publishing Ltd, London.

Dicken, P. (1998) Global Shift. Transforming the World Economy. Paul Chapman Publishing Ltd, London. Drucker P. (2001) 21. századi kihívások a vállalatirányításban. HVG Kiadói Rt., Budapest.

Figyelö (2000) 10.

Fortune (2000) July 31.

Kocsis É.-Szabó K. (2000) A posztmodern vállalat. Tanulás és hálózatosodás az új gazdaságban. Oktatási Minisztérium, Budapest.

Nemes Nagy J. (1998) A tér a társadalomkutatásban. Bevezetés a regionális tudományba. Hilscher Rezső Szociálpolitikai Egyesület, Budapest.

Porter, M.E. (1990) The Competitive Advantage of Nations. Macmillan, London.

Simai M.-Gál P. (2000) Új trendek és stratégiák a világgazdaságban. Vállalatok, államok, nemzetközi szervezetek. Akadémiai Kiadó, Budapest.

Szanyi M. (1997) Elmélet és gyakorlat a nemzetközi mủködőtőke-áramlás vizsgálatában. - Közgazdasági Szemle. Június. 452-477. o.

U.N. UNCTAD (2000) World Investment Report 2000. Cross-border Mergers and Acquisitions and Development. New York.

\section{THE CONCEPT OF STRATEGIC GEOGRAPHIC PLACE IN THE INTERNATIONAL BUSINESS POLICY OF TRANSNATIONAL COMPANIES}

\section{ÁGNES BERNEK}

The strategic geographical place has become the important keyword of the international business in these days. The present world economy has been formed on the basis of the national states and on the hierarchical spatial structure of the metropolitan areas and capital cities, too. In the localization of the transnational corporations the developed industrial countries and the "emerging markets" of the developing countries are the strategic national states. The corporate and regional headquarters of the transnational corporations are sometimes described as the geographical "control points" of the global economy. Budapest is the third best business centre of the Europe in 2000. The networks of the e-business become organized in the virtual space, but there are many geographical places are eliminating from this. 